\title{
PENGENDALI PID PADA BOOST INVERTER SATU FASA DENGAN TEKNIK PENYAKELARAN SPWM BIPOLAR DAN UNIPOLAR
}

\author{
Muh Alif Deby Kurniawan*), Rini Nur Hasanah and Ramadhani Kurniawan Subroto \\ Jurusan Teknik Elektro, Universitas Brawijaya \\ Jalan MT Haryono 167, Malang 65145, Indonesia \\ ${ }^{*}$ E-mail: alifdeby9@gmail.com
}

\begin{abstract}
Abstrak
Artikel ini menguraikan pengendalian dengan metode PID pada boost inverter satu fasa yang menggunakan teknik penyakelaran SPWM bipolar dan unipolar. Kinerja penggunaan kedua teknik penyakelaran dengan pengendali PID dibandingkan dengan jika tidak menggunakan pengendali PID. Metode Integral of Time Absolute Error (ITAE) diterapkan untuk mendapatkan nilai parameter pengendali PID. Penelitian dilakukan dengan metode simulasi menggunakan alat bantu perangkat lunak PSIM. Kinerja didasarkan pada nilai tegangan dan arus keluaran serta nilai total distorsi harmonisa. Hasil penelitian menunjukkan bahwa penggunaan pengendali PID dapat mengurangi nilai total distorsi harmonisa pada boost inverter satu fasa. Penggunaan pengendali PID pada teknik penyakelaran SPWM bipolar menghasilkan pengurangan nilai total distorsi harmonisa hingga sebesar $72,8 \%$, sedangkan pada teknik penyakelaran SPWM unipolar diperoleh pengurangan sebesar hingga 76,7\%. Hasil simulasi juga menunjukkan bahwa besar tegangan dan arus keluaran tetap dapat dipertahankan pada nilai yang diinginkan ketika terjadi gangguan.
\end{abstract}

Kata kunci: boost inverter, metode ITAE, pengendali PID, SPWM bipolar, SPWM unipolar

\begin{abstract}
This article explores the implementation of PID control method on a single-phase boost inverter with bipolar and unipolar SPWM switching techniques. The performances of the PID control on the inverter with the two switching techniques are compared to those without the PID control. The Integral of Time Absolute Error (ITAE) method is applied to get the PID controller parameters. The study was conducted with a simulation method using the PSIM software. The performance evaluation is based on the values of output voltage and current and the total harmonic distortion (THD). The results show that the use of PID controller could reduce the total harmonic distortion in a single-phase inverter boost. The use of PID controller with the bipolar SPWM switching technique resulted in a reduction of the total harmonic distortion of up to $72.8 \%$, while with the unipolar SPWM switching technique a reduction of up to $76.7 \%$ was obtained. Simulation results also show that the voltage and output current could be maintained at the desired value at the time a disturbance occurred.
\end{abstract}

Keywords: boost inverter, bipolar SPWM, ITAE method, PID controller, unipolar SPWM

\section{Pendahuluan}

Konverter elektronika daya memegang peranan yang sangat penting dalam era penggunaan energi baru dan terbarukan. Hal ini karena pada umumnya besar maupun bentuk gelombang tegangan dan arus yang dibangkitkan belum sesuai dengan kebutuhan beban. Sebagai contoh, pada sistem sel surya tegangan yang dibangkitkan tidak dapat langsung dihubungkan dengan beban karena nilainya relatif kecil serta dipengaruhi oleh intensitas pancaran cahaya dan temperatur [1]. Susunan sel surya (photovoltaic array) perlu dilengkapi dengan konverter, misalnya peningkat tegangan DC ( $D C-D C$ boost converter), atau juga pembalik tegangan ( $D C$-AC converter) atau sering disebut dengan inverter, sebelum dapat digunakan untuk mencatu beban AC. Cara seperti ini membutuhkan banyak komponen, volume yang besar, efisiensi yang rendah, dan biaya yang mahal untuk memenuhi kebutuhan beban yang besar [2]. Untuk mengatasi kekurangan tersebut dapat digunakan inverter yang terintegrasi, yang mempunyai tegangan keluaran lebih besar daripada masukannya, atau biasa disebut boost inverter [3]. Boost inverter mempunyai topologi yang tersusun dari dua konverter bidirectional boost DC-DC yang dapat menghasilkan tegangan keluaran AC lebih besar daripada tegangan masukannya serta hanya memerlukan satu tingkat konversi [4].

Penelitian yang dilakukan oleh beberapa peneliti [5][6] menunjukkan bahwa kerumitan rangkaian dapat dikurangi, implementasi dapat dipermudah, serta penyakelaran yang sederhana dapat diperoleh dengan menggunakan metode Sinusoidal Pulse- Width Modulation (SPWM) bipolar pada boost inverter. Metode SPWM merupakan salah satu teknik penyakelaran dalam bidang PWM yang diperoleh 
dengan membandingkan sinyal referensi (sinusoidal) dengan sinyal pembawa (carrier) yang berbentuk sinyal segitiga. Metode SPWM secara umum dikategorikan menjadi dua jenis teknik penyakelaran yaitu bipolar dan unipolar [7][8].

Berbagai jenis pengendali sering dimanfaatkan untuk memperoleh karakteristik keluaran sistem konverter yang sesuai dengan kebutuhan, misalnya diinginkan agar diperoleh tegangan keluaran yang stabil ketika ada perubahan beban. Pengendali PID, yang merupakan salah satu dari pengendali yang paling banyak digunakan, menggabungkan keuntungan aksi pengendalian proporsional (P), integratif (I), dan derivatif (D). Pengendali proporsional secara umum dikenal menghasilkan efek mengurangi tapi tidak pernah dapat menghilangkan durasi waktu lonjakan aksi pengendalian. Jika pengendali integratif ditambahkan, sinyal pengendali akan sebanding dengan hasil integrasi besarnya kesalahan. Pengendali PID juga dikenal dapat menghasilkan nilai THD yang lebih baik.

Nilai parameter pengendali PID dapat ditentukan dengan berbagai cara, salah satunya dengan metode Integral of Time Absolute Error (ITAE) [9][10]. Metode ini didasarkan pada optimasi hasil integrasi kesalahan absolut yang diboboti terhadap waktu. Pencarian nilai parameter $K_{\mathrm{p}}, K_{\mathrm{i}}$ dan $K_{\mathrm{d}}$ dapat dilakukan dengan bantuan tabel persamaan ITAE. Hasil penelitian mengenai pengendalian PID suatu buck-boost inverter menggunakan metode ITAE menunjukkan bahwa tegangan keluaran yang cenderung stabil serta nilai THD yang lebih baik dapat diperoleh meskipun beban mengalami perubahan [9]. Tegangan keluaran inverter yang cenderung stabil saat beban mengalami perubahan juga diperoleh dari hasil penerapan pada buck inverter atau inverter konvensional [11].

Tujuan artikel ini adalah pertama untuk menunjukkan bahwa boost inverter dengan pengendali PID dapat memperbaiki THD jika dibandingkan dengan tanpa PID. Kedua untuk menunjukkan bahwa boost inverter dengan pengendali PID jika diberi 3 macam gangguan yaitu merubah beban resistor $(\mathrm{R})$, tegangan masukan $\left(\mathrm{V}_{\text {in }}\right)$ dan tegangan referensi $\left(\mathrm{V}_{\text {ref }}\right)$ dapat memperoleh tegangan keluaran $\left(\mathrm{V}_{\text {out }}\right)$ dengan kondisi stabil.

Berbeda dengan pada [9], dalam paper ini metode ITAE digunakan pada pengendalian PID untuk boost inverter satu fasa dengan teknik penyakelaran SPWM unipolar dan bipolar. Penelitian dilakukan menggunakan metode simulasi dengan memanfaatkan perangkat lunak PSIM.

\section{Metode}

\subsection{Perancangan Boost Inverter Satu Fasa}

Rangkaian pengganti boost inverter satu fasa yang digunakan dalam penelitian ditampilkan pada Gambar 1, sedangkan spesifikasi parameter awalnya ditampilkan pada Tabel 1.

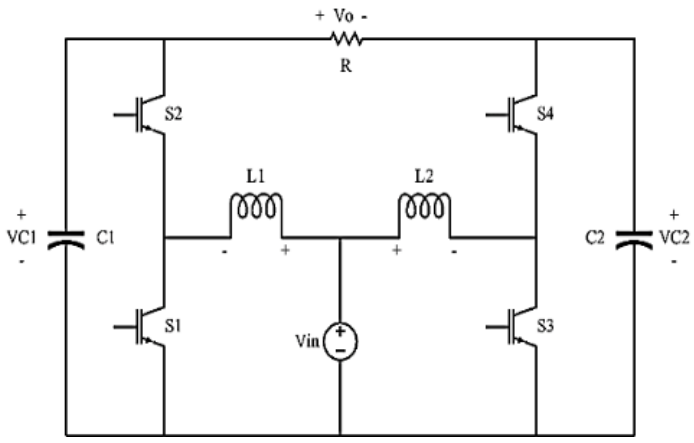

Gambar 1. Rangkaian boost inverter satu fasa

Tabel 1 Spesifikasi Parameter Awal Boost Inverter

\begin{tabular}{llll}
\hline No. & Parameter & Nilai & Satuan \\
\hline 1. & Vin & 48 & Volt DC \\
2. & Vop & 220 & Volt AC \\
3. & $\mathrm{R}$ & 100 & Ohm \\
4. & $\mathrm{f}_{\mathrm{S}}$ & 10000 & $\mathrm{~Hz}$ \\
5. & $\Delta \mathrm{I}_{\mathrm{L}}$ & 0,2 & ampere \\
\hline
\end{tabular}

Sebagaimana terlihat pada Gambar 1, rangkaian tersebut terdiri dari beberapa komponen antara lain dua induktor, dua kapasitor, empat saklar elektronika daya, dalam hal ini IGBT, dan satu beban resistor.

Berdasarkan spesifikasi yang diberikan pada Tabel 1, langkah selanjutnya adalah menentukan parameter nilai komponen induktor $1\left(L_{1}\right)$ dan $2\left(L_{2}\right)$ boost inverter. Yang pertama adalah mencari nilai parameter duty cycle maksimal $\left(D_{\max }\right)$,

$$
D_{\max }=\frac{V_{i n}}{2 V_{o p}}\left[\frac{V_{o p}}{V_{i n}}-2+\sqrt{\left(\frac{V_{o p}}{V_{i n}}\right)^{2}+4}\right]
$$

yang menghasilkan nilai $D_{\max }$ sebesar 0,83 .

Perhitungan nilai parameter arus induktor maksimal $\left(I_{\mathrm{Lmax}}\right)$ dilakukan menggunakan (2),

$$
I_{L \max }=\frac{V_{i n}\left(2 D_{\max }-1\right)}{R D_{\max }\left(1-D_{\max }\right)^{2}}
$$

yang menghasilkan nilai $I_{\text {Lmax }}$ sebesar 13,21 A.

Nilai parameter induktor $1 \quad\left(L_{1}\right)$ dan $2 \quad\left(L_{2}\right)$ dicari menggunakan (3),

$$
L_{1}=L_{2}=L=\frac{V_{\text {in }} D_{\max }}{f_{s} I_{L \max } \Delta I_{L}}
$$

yang menghasilkan nilai $L$ sebesar $1510 \mu \mathrm{H}$.

Penentuan nilai kapasitor $1\left(C_{1}\right)$ dan $2\left(C_{2}\right)$ menggunakan bantuan grafik pada Gambar 2. Pada penelitian ini harmonisa yang diinginkan sekitar 5\%, sehingga sesuai 
dengan Gambar 2 dibutuhkan nilai kapasitor $1\left(C_{1}\right)$ dan 2 $\left(C_{2}\right)$ sebesar $2 \mu \mathrm{F}$.

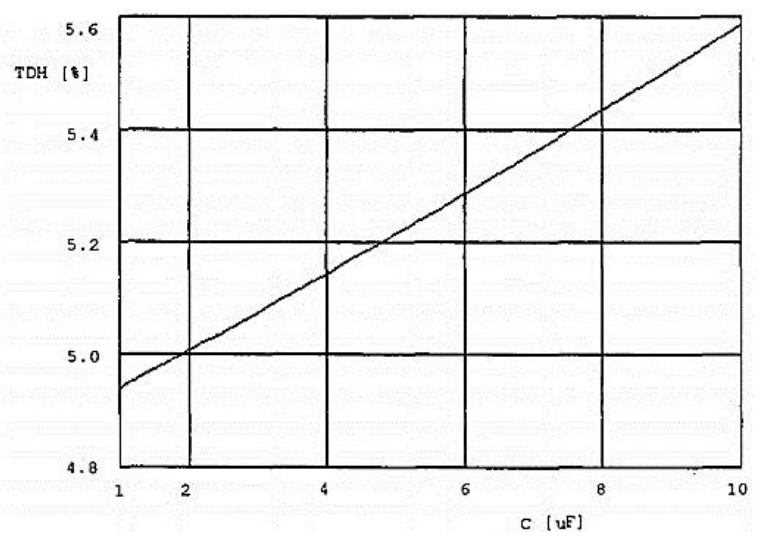

Gambar 2. Grafik harmonisa terhadap kapasitor

\subsection{Perancangan SPWM Bipolar dan Unipolar untuk Boost Inverter}

Parameter SPWM bipolar dan unipolar antara lain, rasio modulasi frekuensi $\left(m_{\mathrm{f}}\right)$ dan rasio modulasi amplitudo $\left(m_{\mathrm{a}}\right)$, dengan didasarkan pada spesifikasi parameter awal yang diberikan pada Tabel 2.

Tabel 2 Spesifikasi Parameter Awal SPWM Boost Inverter

\begin{tabular}{llll}
\hline No. & Parameter & Nilai & Satuan \\
\hline 1. & $\mathrm{f}_{\text {reference }}$ & 50 & $\mathrm{~Hz}$ \\
2. & $\mathrm{f}_{\text {carrier }}$ & 10000 & $\mathrm{~Hz}$ \\
3. & Vm,reference & 0,71 & Volt \\
4. & Vm,carrier & 1 & Volt \\
\hline
\end{tabular}

Berdasarkan Tabel 2 dapat ditentukan rasio modulasi amplitudo $\left(m_{\mathrm{a}}\right)$ dan frekuensi $\left(m_{\mathrm{f}}\right)$ pada pensaklaran SPWM bipolar dan unipolar. Perhitungan untuk mencari nilai parameter rasio modulasi frekuensi $\left(m_{\mathrm{f}}\right)$ adalah sebagai berikut,

$$
m_{f}=\frac{f_{\text {carrier }}}{f_{\text {reference }}}=\frac{f_{\text {tri }}}{f_{\text {sin }}}=\frac{10000 \mathrm{~Hz}}{50 \mathrm{~Hz}}=200
$$

Perhitungan untuk mencari nilai parameter rasio modulasi amplitudo $\left(m_{\mathrm{a}}\right)$ atau biasa disebut indeks modulasi pada SPWM adalah sebagai berikut,

$$
m_{a}=\frac{V_{m, \text { referene }}}{V_{m, \text { carrier }}}=\frac{V_{m, \text { sin }}}{V_{m, t r i}}=\frac{0,71 \text { volt }}{1 \text { volt }}=0,71
$$

\subsection{Perancangan Pengendali PID Metode ITAE untuk Boost Inverter}

Metode ITAE merupakan metode untuk mencari nilai parameter pengendali PID yaitu $K_{p}, K_{i}$ dan $K_{d}$. Parameter pengendali tersebut didapatkan dengan menurunkan beberapa persamaan [9] sehingga diperoleh persamaan (12) s/d (14). Presentase yang dimunculkan adalah presentase THD pada dua kondisi yaitu boost inverter dengan menggunakan PID dan tanpa PID.

Penerapan metode ITAE dilakukan dengan pertama-tama menentukan model matematika boost inverter tanpa pengendali PID dengan cara mencari fungsi alihnya [10], [12][13][14][15][16]. Persamaan (4) merupakan persamaan fungsi alih dari boost invetrer.

$\frac{\hat{v_{o}}}{\hat{d}}=R_{\text {load }} \frac{X_{1} s^{3}+X_{2} s^{2}+X_{3} s+X_{4}}{Y_{1} s^{4}+Y_{2} s^{3}+Y_{3} s^{2}+Y_{4} s+Y_{5}}$

dengan,

$X_{1}=\left(I_{a}+I_{b}\right) C L^{2}$

$X_{2}=\left(D V_{b}-(1-D) V_{a}\right) C L$

$Y_{5}=R_{\text {load }} D^{2}(1-D)^{2}$

$X_{3}=\left(I_{a} D^{2}+I_{b}(1-D)^{2}\right) L$

$X_{4}=\left((1-D) V_{b}-D V_{a}\right)(1-D) D$

$Y_{1}=R_{\text {load }} C^{2} L^{2}$

$I_{a}=-\frac{(2 D-1) V_{i n}}{D(1-D)^{2} R}$

$I_{b}=\frac{(2 D-1) V_{i n}}{D^{2}(1-D) R}$

$Y_{2}=2 C L^{2}$

$Y_{3}=R C L\left(1-2 D+2 D^{2}\right)$

$Y_{4}=L\left(1-2 D+2 D^{2}\right)$

$V_{a}=\frac{-V_{\text {in }}}{1-D}$

$V_{b}=\frac{V_{\text {in }}}{D}$

Selanjut grafik respon step boost inverter dicari dengan menggunakan alat bantu perangkat lunak Matlab sesuai dengan nilai-nilai pada Tabel 3, yang menghasilkan grafik respon step seperti yang ditunjukkan pada Gambar 3 .

Tabel 3 Spesifikasi Awal Step Respon Boost Inverter

\begin{tabular}{llll}
\hline No. & Parameter & Nilai & Satuan \\
1. & $V_{\text {in }}$ & 48 & volt DC \\
2. & $R$ & 100 & ohm \\
3. & $C$ & 2 & $\mu \mathrm{F}$ \\
4. & $L$ & 1600 & $\mu \mathrm{H}$ \\
5. & $D$ & 0,65 & - \\
\hline
\end{tabular}

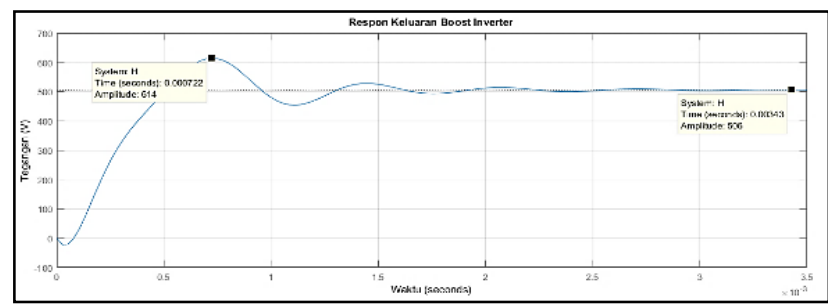

Gambar 3. Grafik step response keluaran boost inverter tanpa pengendali PID

Berdasarkan Gambar 3 didapatkan nilai parameter $t_{p}$ sebesar $7,22 \times 10^{-4}$ detik, $\mathrm{V}_{\text {oss }}$ sebesar $506 \mathrm{~V}$, dan $V_{\mathrm{p}}$ sebesar $614 \mathrm{~V}$. Kemudian mencari nilai parameter $\zeta$ (rasio redaman sistem) yaitu sebagai berikut, 


$$
\begin{aligned}
& M_{p}=\frac{V_{p}-\text { Voss }}{\text { Voss }} \times 100 \% \\
& M_{p}=\frac{614-506}{506} \times 100 \% \\
& M_{p}=21,34 \% \\
& \% M_{p}=0,21
\end{aligned}
$$

Kemudian,

$$
\begin{aligned}
& \% M_{p}=e^{-\pi\left(\frac{\zeta}{\sqrt{1-\zeta^{2}}}\right)} \\
& 0,21=e^{-\pi\left(\frac{\zeta}{\sqrt{1-\zeta^{2}}}\right)} \\
& \ln (0,21)=\ln \left(e^{-\pi\left(\frac{\zeta}{\sqrt{1-\zeta^{2}}}\right)}\right) \\
& -1,54=-\frac{\pi \zeta}{\sqrt{1-\zeta^{2}}} \\
& \zeta=0,44
\end{aligned}
$$

Kemudian mencari nilai parameter $\omega_{\mathrm{n}}^{*}$ (frekuensi alamiah lama) yaitu sebagai berikut,

$$
\begin{aligned}
& t_{p}=\frac{\pi}{\omega_{n}^{*} \sqrt{1-\zeta^{2}}} \\
& 7,22 \times 10^{-4}=\frac{\pi}{\omega_{n}^{*} \sqrt{1-0,44^{2}}} \\
& \omega_{n}^{*}=4846,61 \mathrm{rad} / \mathrm{s}
\end{aligned}
$$

Langkah selanjutnya adalah membuat diagram blok pengendali PID saat kondisi closed loop pada boost inverter yang ditunjukkan pada Gambar 4.

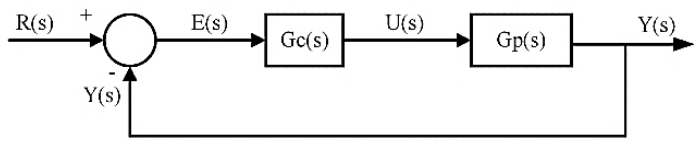

Gambar 4. Blok diagram sistem boost inverter kondisi closed loop

Gambar 4 merupakan diagram blok pengendali PID saat kondisi closed loop pada boost inverter. Dari Gambar 4 dapat diperoleh beberapa model matematika dari sistem closed loop antara lain sebagai berikut,

$$
G_{p}(s)=\frac{K}{S^{2}+\alpha S+\beta}
$$

Persamaan (5) merupakan persamaan fungsi alih boost inverter yang akan dibandingkan dengan persamaan sistem orde dua dari boost inverter berikut,

$$
G_{p}(S)=\frac{K^{*} \omega_{n}^{2}}{S^{2}+2 \zeta \omega_{n} S+\omega_{n}^{2}}=\frac{\frac{V_{o s s}}{U} \omega_{n}^{2}}{S^{2}+2 \zeta \omega_{n} S+\omega_{n}^{2}}
$$

Selanjutnya dihasilkan persamaan (7)

$$
K=K^{*} \omega_{n}^{2}=\frac{V_{o s s}}{U} \omega_{n}^{2} ; \alpha=2 \zeta \omega_{n} ; \beta=\omega_{n}^{2}
$$

dengan,

$\mathrm{U}:$ : duty cycle.

$\omega_{\mathrm{n}} \quad$ : frekuensi alamiah $(\mathrm{rad} / \mathrm{s})$.

$\zeta \quad$ : rasio peredaman sistem.

$\mathrm{V}_{\text {oss }} \quad$ : tegangan keluaran step respon pada kondisi steady (volt).

Persamaan (8) merupakan persamaan fungsi alih pengendali PID,

$$
G_{c}(s)=\frac{K_{d} S^{2}+K_{p} S+K_{i}}{S}
$$

dengan,

$\mathrm{G}_{\mathrm{c}}(\mathrm{s}) \quad$ : fungsi alih pengendali PID.

$\mathrm{K}_{\mathrm{d}} \quad$ : penguatan diferensial.

$\mathrm{K}_{\mathrm{p}} \quad$ : penguatan proporsional.

$\mathrm{K}_{\mathrm{i}} \quad$ : penguatan integral.

Persamaan (9) merupakan persamaan fungsi alih sistem secara closed loop,

$$
T(s)=\frac{G_{c}(s) G_{p}(s)}{1+G_{c}(s) G_{p}(s)}
$$

Substitusi persamaan (5) dan (8) ke persamaan (9) menghasilkan persamaan (10),

$$
T(S)=\frac{\left(K_{d} S^{2}+K_{p} S+K_{i}\right) K}{S^{3}+\left(\alpha+K K_{d}\right) S^{2}+\left(\beta+K K_{p}\right) S+K K_{i}}
$$

Persamaan (10) merupakan persamaan lengkap fungsi alih sistem closed loop dengan pengendali PID, dengan

$\mathrm{K}_{\mathrm{d}} \quad$ : penguatan diferensial.

$\mathrm{K}_{\mathrm{p}} \quad$ : penguatan proporsional.

$\mathrm{K}_{\mathrm{i}} \quad$ : penguatan integral.

$\mathrm{K} \quad$ : penguatan sistem.

Dari persamaan (10) dapat diperoleh persamaan karakteristik ITAE. Persamaan karakteristik ITAE merupakan persamaan yang diperoleh dengan menggunakan metode ITAE yang diperoleh dari tabel ITAE pada Tabel 4.

\section{Tabel 4 Persamaan Karakteristik ITAE}

\begin{tabular}{ll}
\hline No. & Persamaan ITAE \\
\hline 1. & $\mathrm{S}+\omega_{\mathrm{n}}$ \\
2. & $\mathrm{S}^{2}+1,4 \omega_{\mathrm{n}} \mathrm{S}+\omega_{\mathrm{n}}^{2}$ \\
3. & $\mathrm{S}^{3}+1,75 \omega_{\mathrm{n}} \mathrm{S}^{2}+2,15 \omega_{\mathrm{n}}^{2} \mathrm{~S}+\omega_{\mathrm{n}}^{3}$ \\
4. & $\mathrm{S}^{4}+2,1 \omega_{\mathrm{n}} \mathrm{S}^{3}+3,4 \omega_{\mathrm{n}}^{2} \mathrm{~S}^{2}+2,7 \omega_{\mathrm{n}}^{3} \mathrm{~S}+\omega_{\mathrm{n}}^{4}$ \\
\hline
\end{tabular}

Dengan melihat penyebut dari persamaan (10), yang biasa disebut persamaan karakteristik sistem, selanjutnya dilakukan perbandingan dengan persamaan serupa yang 
ada pada Tabel 4. Akan diperoleh persamaan karakteristik ITAE berikut ini,

$$
S^{3}+1,75 \omega_{n} S^{2}+2,15 \omega_{n}^{2} S+\omega_{n}^{3}
$$

Membandingkan persamaan (10) dengan persamaan (11) akan memberikan persamaan $K_{\mathrm{p}} K_{\mathrm{i}}$ dan $K_{\mathrm{d}}$ sebagaimana diberikan pada persaman (12)-(14).

$$
K_{d}=\frac{1.75 \omega_{n}-2 \zeta \omega_{n}}{\frac{\omega_{n}^{2} V o s s}{U}}
$$

Persamaan (12) merupakan persamaan untuk menghitung nilai parameter $\mathrm{K}_{\mathrm{d}}$ dengan,

$\zeta \quad$ : rasio peredaman sistem.

$\mathrm{V}_{\text {oss }} \quad$ : Tegangan steady state (volt).

U : Duty cycle (\%).

$\omega_{\mathrm{n}} \quad:$ frekuensi alamiah $(\mathrm{rad} / \mathrm{s})$

yang nilai-nilainya diberikan pada Tabel 5.

Nilai parameter $\mathrm{K}_{\mathrm{p}}$ dihitung menggunakan persamaan (13),

$$
K_{p}=\frac{2.15 \omega_{n}^{2}-\omega_{n}^{2}}{\frac{\omega_{n}^{2} \text { Voss }}{U}}
$$

Nilai parameter $K_{\mathrm{i}}$ dihitung menggunakan persamaan (14),

$$
K_{i}=\frac{\omega_{n}^{3}}{\frac{\omega_{n}^{2} \operatorname{Voss}}{U}}
$$

Paremeter untuk pengendali PID antara lain $\mathrm{Kp}, \mathrm{Ki}$, dan Kd. Untuk mencari ketiga parameter tersebut diperlukan nilai parameter $\omega_{\mathrm{n}}$, Voss, $U$ dan $\zeta$. Untuk penentuan nilai $\omega_{n}$ dicari dengan memasukkan nilai $\omega_{n}$ lama yaitu $\omega_{n}^{*}$ terlebih dahulu untuk menentukan Kp, Ki dan Kd. Jika Kp, $\mathrm{Ki}$ dan Kd tidak sesuai maka dilakukan penentuan ulang nilai $\omega_{\mathrm{n}}$ kemudian dilakukan verifikasi lagi apakah sesuai atau tidak sampai menemukan nilai $\omega_{n}$ yang sesuai dengan hasil keluaran yang diinginkan.

\section{Tabel 5 Spesifikasi Parameter Awal Pengendali PID}

\begin{tabular}{llll}
\hline No. & Parameter & Nilai & Satuan \\
\hline 1. & $\omega_{\mathrm{n}}$ & 8500 & Rad/s \\
2. & $\mathrm{V}_{\text {oss }}$ & 506 & Volt \\
3. & $\mathrm{U}$ & 0,65 & - \\
4. & $\zeta$ & 0,4414 & - \\
\hline
\end{tabular}

Berdasarkan Tabel 5 dapat ditentukan nilai parameter $K_{\mathrm{p}}$, $K_{\mathrm{i}}$ dan $K_{\mathrm{d}}$ pengendali PID metode ITAE, yang menghasilkan nilai $K_{p}=1,48 \times 10^{-3}, K_{i}=10,92$, dan $K_{d}=1,31 \times 10^{-7}$.

\subsection{Gambaran Umum Sistem Boost Inverter}

Gambaran umum sistem boost inverter yang diberikan pada Gambar 5 dimaksudkan untuk memudahkan mengetahui keseluruhan sistem boost inverter lengkap dengan pengendali PID.

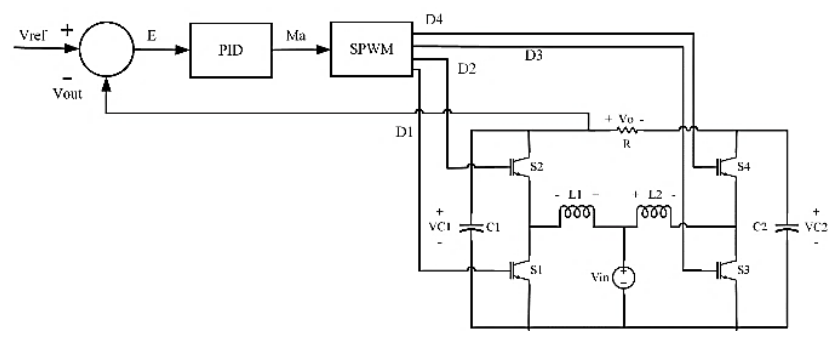

Gambar 5. Gambaran umum sistem boost inverter secara keseluruhan

Mengacu pada Gambar 5 terlihat bahwa boost inverter menggunakan teknik pensakelaran SPWM yang dihubungkan dengan empat saklar elektronik (IGBT). Pensakelaran SPWM dikendalikan dengan pengendali PID metode ITAE. Masukan pengendali PID berupa nilai error (E) atau selisih dari tegangan referensi ( $\left.V_{\text {ref }}\right)$ dengan tegangan keluaran $\left(V_{\text {out }}\right)$ boost inverter. Masukan SPWM adalah rasio modulasi amplitudo $\left(M_{\mathrm{a}}\right)$ atau biasa disebut indeks modulasi. Keluaran SPWM berupa gelombang pulsa (D1, D2, D3 dan D4).

\subsection{Simulasi Rangkaian Boost Inverter dengan Pengendali PID}

Simulasi terlebih dahulu dilakukan pada boost inverter menggunakan SPWM bipolar dan unipolar tanpa pengendali PID. Rangkaian simulasi ditunjukkan pada Gambar 6 dan 7, dengan menggunakan spesifikasi yang diberikan pada Tabel 6 .

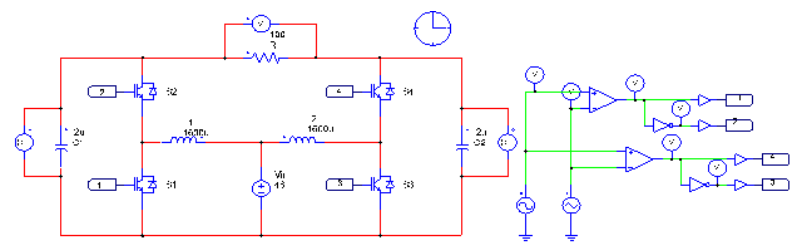

Gambar 6. Rangkaian boost inverter tanpa pengendali PID SPWM bipolar pada PSIM

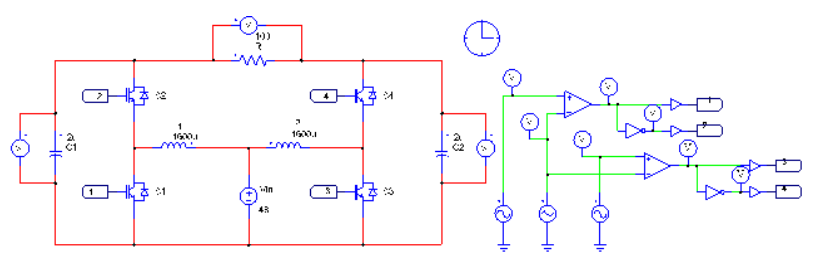

Gambar 7. Rangkaian boost inverter tanpa pengendali PID SPWM unipolar pada PSIM 
Tabel 6. Spesifikasi Boost Inverter SPWM Bipolar dan Unipolar Tanpa Pengendali PID

\begin{tabular}{llll}
\hline No. & Parameter & Nilai & Satuan \\
\hline 1. & Vin & 48 & $\mathrm{VDC}$ \\
2. & $\mathrm{L} 1$ \& $\mathrm{L} 2$ & 1600 & $\mu \mathrm{H}$ \\
3. & $\mathrm{C} 1$ \& 22 & 2 & $\mu \mathrm{F}$ \\
4. & $\mathrm{R}$ & 100 & $\mathrm{Ohm}$ \\
$\mathbf{5 .}$ & $\mathrm{f}_{\text {referensi }}$ & 50 & $\mathrm{~Hz}$ \\
$\mathbf{6 .}$ & $\mathrm{f}_{\text {carrier }}$ & 10000 & $\mathrm{~Hz}$ \\
7. & $\mathrm{V}_{\text {m,referensu }}$ & 0,71 & volt \\
$\mathbf{8 .}$ & $\mathrm{V}_{\mathrm{m}, \text { carrier }}$ & 1 & volt \\
\hline
\end{tabular}

Simulasi dilakukan dengan menggunakan aplikasi komputer PSIM. Dilakukan pengamatan terhadap hasil keluaran $V_{\text {out }}$ dan distorsi harmonik total (THD) yang diperoleh. Identifikasi THD dilakukan menggunakan bantuan analisis FFT yang ada pada aplikasi komputer PSIM.

Simulasi selanjutnya dilakukan pada boost inverter menggunakan SPWM bipolar dan unipolar dengan pengendali PID kondisi closed loop. Rangkaian simulasi ditunjukkan pada Gambar 8 dan 9 serta Tabel 7 merupakan tabel spesifikasi yang digunakan pada boost inverter dengan pengendali PID kondisi closed loop.

Pengamatan terhadap hasil simulasi dilakukan pada keluaran hasil $V_{\text {out }}$ dan THD. THD diidentifikasi dengan memanfaatkan bantuan analisis FFT yang ada di aplikasi komputer PSIM.

\subsection{Analisis Perbandingan Kinerja Boost Inverter}

Analisis perbandingan kinerja boost inverter satu fasa dilakukan dengan melihat nilai THD tegangan dan arus keluaran antara tanpa pengendali PID dan dengan pengendali PID. Perhitungan THD dilakukan dengan menggunakan bantuan aplikasi komputer Excel, sedangkan analisis FFT menggunakan bantuan aplikasi komputer PSIM.

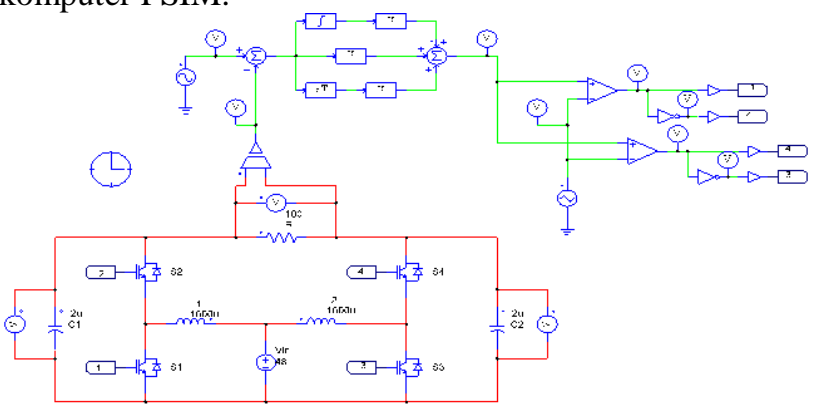

Gambar 8. Boost inverter dengan pengendali PID SPWM bipolar pada PSIM

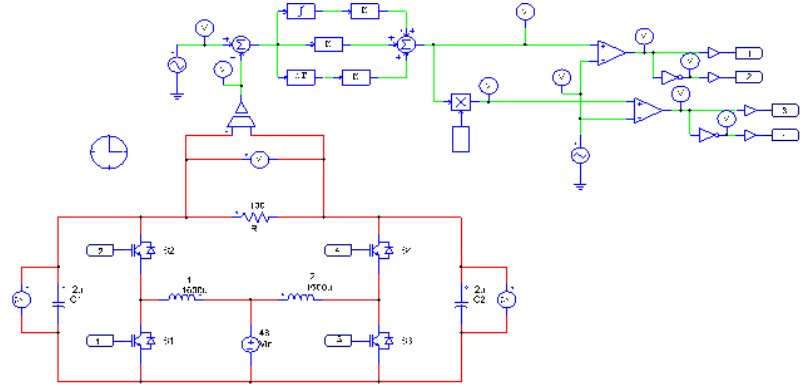

Gambar 9. Boost inverter dengan pengendali PID SPWM unipolar pada PSIM

Tabel 7. Spesifikasi Boost Inverter SPWM Bipolar dan Unipolar dengan Pengendali PID

\begin{tabular}{llll}
\hline No. & Parameter & Nilai & Satuan \\
\hline 1. & Vin & 48 & $\mathrm{VDC}$ \\
2. & $\mathrm{L} 1$ \& $\mathrm{L} 2$ & 1600 & $\mu \mathrm{H}$ \\
3. & $\mathrm{C} 1 \& \mathrm{C} 2$ & 2 & $\mu \mathrm{F}$ \\
4. & $\mathrm{R}$ & 100 & $\mathrm{Ohm}$ \\
5. & $\mathrm{f}_{\text {referensi }}$ & 50 & $\mathrm{~Hz}$ \\
6. & $\mathrm{f}_{\text {carrier }}$ & 10000 & $\mathrm{~Hz}$ \\
7. & $\mathrm{V}_{\mathrm{m}, \text { carrier }}$ & 1,5 & $\mathrm{Volt}$ \\
8. & $\mathrm{K}_{\mathrm{p}}$ & $1,48 \times 10^{-3}$ & - \\
9. & $\mathrm{K}_{\mathrm{i}}$ & 10,92 & - \\
10. & $\mathrm{K}_{\mathrm{d}}$ & $1,31 \times 10^{-7}$ & - \\
\hline & & &
\end{tabular}

Pengujian boost inverter dilakukan pada pengendali PID kondisi closed loop dengan memberikan gangguan berupa perubahan nilai beban resistor $(R)$ dengan variasi $87,4 \mathrm{ohm}$ - $200 \mathrm{ohm}$, tegangan masukan $\left(V_{\text {in }}\right)$ dengan variasi 46 volt - 96 volt dan tegangan referensi $\left(V_{\text {ref }}\right)$ dengan variasi 110 228 volt untuk melihat kinerja pengendali PID pada boost inverter. Pengujian bertujuan untuk mengetahui apakah nilai $V_{\text {out }}$ cenderung stabil jika diberikan gangguan.

Inverter memiliki beberapa parameter kinerja salah satunya adalah THD. THD merupakan rasio nilai rms dari komponen harmonisa terhadap nilai rms dari komponen dasar yang biasanya dinyatakan dalam persen (\%). Berikut merupakan persamaan untuk mendapatkan nilai THD,

$$
T H D=\frac{\sqrt{\sum_{n=2}^{\infty}\left(V_{n, r m s}\right)^{2}}}{V_{1, r m s}}=\frac{\sqrt{V_{r m s}^{2}-V_{1, r m s}^{2}}}{V_{1, r m s}}
$$

Persamaan (15) merupakan persamaan untuk menghitung nilai total distorsi harmonik dengan,

THD : total distorsi harmonik (\%).

$\mathrm{V}_{\mathrm{n}, \mathrm{rms}} \quad$ : tegangan rms harmonisa ke-n (volt).

$\mathrm{V}_{1, \text { rms }} \quad$ : tegangan rms fundamental (volt).

$\mathrm{n} \quad$ : komponen harmonisa maksimum ke-n. 


\section{Analisis Hasil}

Hasil simulasi boost inverter dengan pengendali PID untuk SPWM Bipolar dan Unipolar dibandingkan dengan pengendali SPWM [5]. Pada penelitian tersebut didapatkan nilai THD sebesar $19,1 \%$.

\subsection{Hasil Simulasi Boost Inverter tanpa Pengendali PID SPWM Bipolar dan Unipolar}

Hasil simulasi boost inverter tanpa pengendali PID SPWM bipolar dan unipolar ditunjukkan pada Gambar 10 - 13 Simulasi dilakukan dengan durasi waktu simulasi 0,2 detik, dengan waktu stepnya $5 \times 10^{-6}$ detik serta menggunakan spesifikasi pada tabel 2. Grafik keluaran tegangan dan arus untukSPWM bipolar ditunjkkan pada gambar 10 dan 11 , sedangkan untuk yang unipolar diberikan pada Gambar 12 dan 13 .

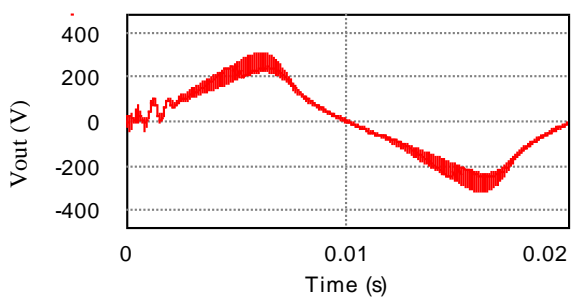

Gambar 10. Grafik $V_{\text {out }}$ boost inverter SPWM bipolar tanpa pengendali PID

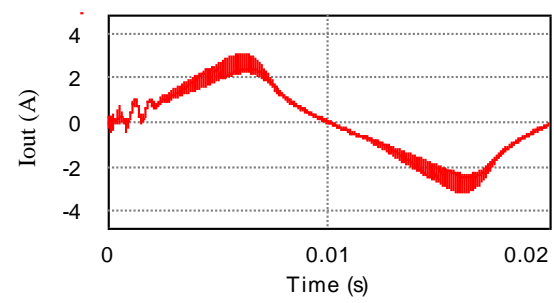

Gambar 11. Grafik $I_{\text {out }}$ boost inverter SPWM bipolar tanpa pengendali PID

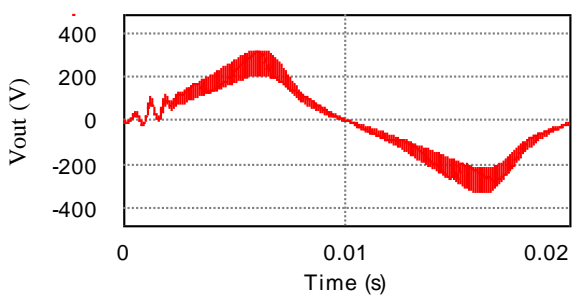

Gambar 12. Grafik $V_{\text {out }}$ boost inverter SPWM unipolar tanpa pengendali PID

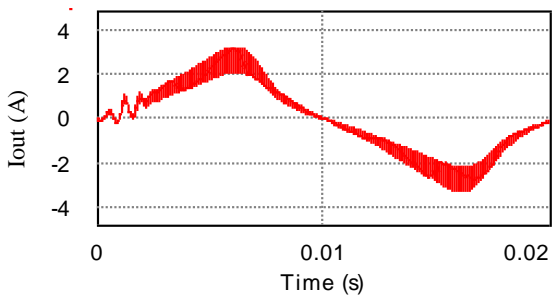

Gambar 13. Grafik $I_{\text {out }}$ boost inverter SPWM unipolar tanpa pengendali PID

\subsection{Perbandingan Kinerja Boost Inverter tanpa} Pengendali PID SPWM Bipolar dan Unipolar

Berdasarkan Gambar 10-13 maka diperoleh perbandingan hasil simulasi boost inverter tanpa pengendali PID SPWM bipolar dan unipolar yang ditunjukkan pada Tabel 8, Gambar 14 dan 15.

Tabel 8. Perbandingan Boost Inverter tanpa Pengendali PID Antara SPWM Bipolar dengan Unipolar

\begin{tabular}{lllll}
\hline No. & Parameter & \multicolumn{2}{c}{ Nilai SPWM } & Satuan \\
& & Bipolar & Unipolar & \\
\hline 1. & Vout & 221,88 & 220,73 & V \\
2. & lout & 2,22 & 2,21 & $\mathrm{~A}$ \\
3. & THD & 19,69 & 19,78 & $\%$ \\
4. & THD $_{\text {lout }}$ & 19,69 & 19,78 & $\%$ \\
\hline
\end{tabular}

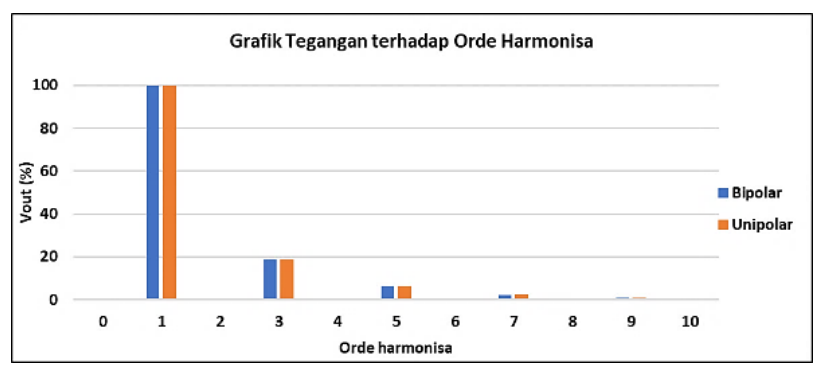

Gambar 14. Grafik perbandingan boost inverter $V_{\text {out }}$ terhadap orde harmonisa tanpa pengendali PID SPWM bipolar dan unipolar

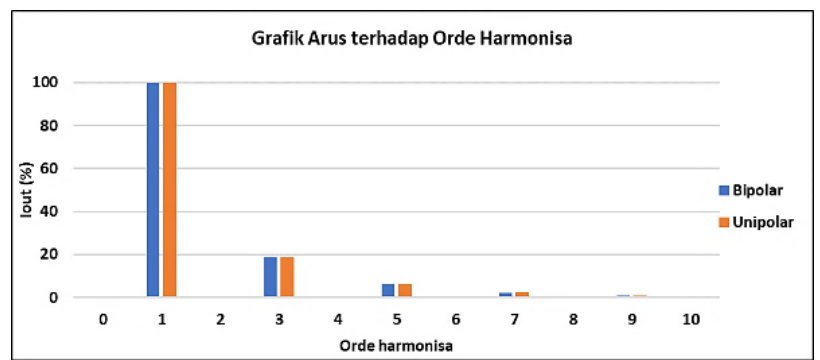

Gambar 15. Grafik perbandingan boost inverter $I_{\text {out }}$ terhadap orde harmonisa tanpa pengendali PID antara SPWM bipolar dengan unipolar 


\subsection{Hasil Simulasi Boost Inverter dengan Pengendali PID SPWM Bipolar dan Unipolar}

Simulasi boost inverter dengan pengendali PID SPWM bipolar dan unipolar dilakukan dengan durasi waktu simulasi 0,2 detik, waktu stepnya $5 \times 10^{-6}$ detik serta menggunakan spesifikasi pada Tabel 3. Hasil simulasi yang diamati adalah tegangan keluaran dan arus keluaran boost inverter, seperti yang ditunjukkan pada Gambar 1619.

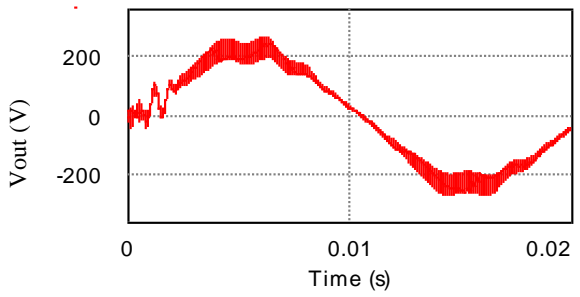

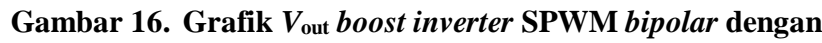
pengendali PID

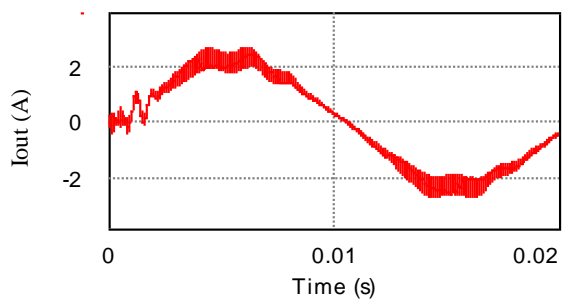

Gambar 17. Grafik $I_{\text {out }}$ boost inverter SPWM bipolar dengan pengendali PID

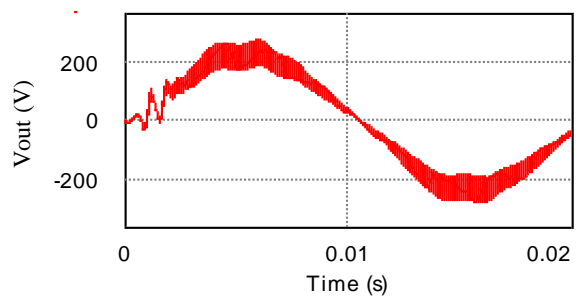

Gambar 18. Grafik $V_{\text {out }}$ boost inverter SPWM unipolar dengan pengendali PID

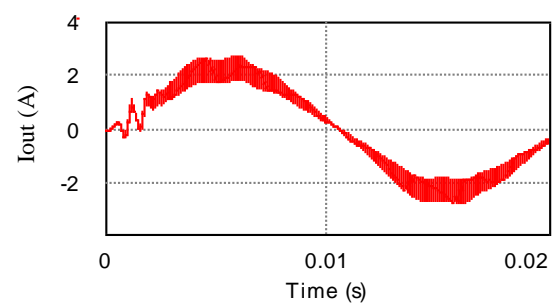

Gambar 19. Grafik $I_{\text {out }}$ boost inverter SPWM unipolar dengan pengendali PID

Boost inverter SPWM bipolar pengendali PID diberi gangguan berupa perubahan nilai $V_{\text {ref }}, V_{\text {in }}$, dan $R_{\text {load }}$ pada waktu ke-0,1 detik. Pemberian gangguan tersebut dilakukan untuk mengetahui bagaimana kinerja pengendali PID pada boost inverter pensakelaran SPWM bipolar. Hasil simulasi pemberian gangguan tersebut ditunjukkan pada Gambar 20-31.

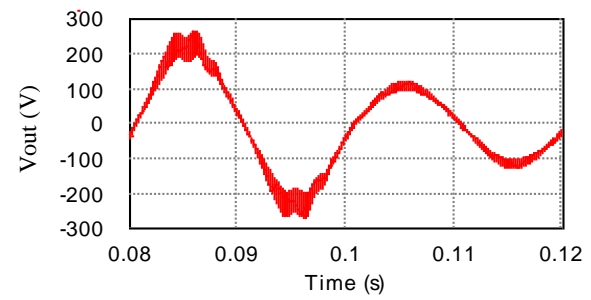

Gambar 20. Grafik $V_{\text {out }}$ boost inverter SPWM bipolar dengan pengendali PID $V_{\text {ref }} 220$ volt menjadi 110 volt

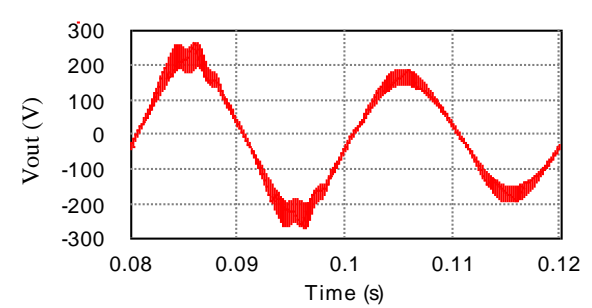

Gambar 21. Grafik $V_{\text {out }}$ boost inverter SPWM bipolar dengan pengendali PID $V_{\text {ref }} 220$ volt menjadi 165 volt

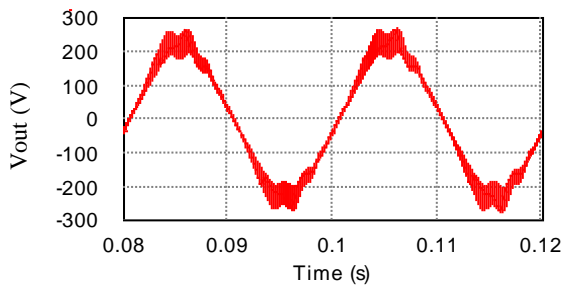

Gambar 22. Grafik $V_{\text {out }}$ boost inverter SPWM bipolar dengan pengendali PID $V_{\text {ref }} 220$ volt menjadi 222 volt

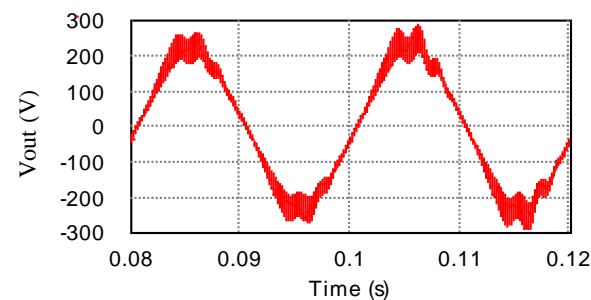

Gambar 23. Grafik $V_{\text {out }}$ boost inverter SPWM bipolar dengan pengendali PID $V_{\text {ref }} 220$ volt menjadi 228 volt

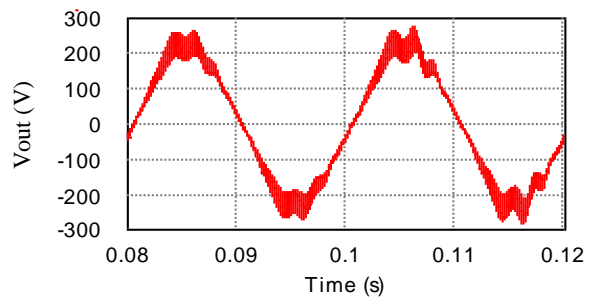

Gambar 24. Grafik $V_{\text {out }}$ boost inverter SPWM bipolar dengan pengendali PID $V_{\text {in }} 48$ volt menjadi 46 volt

DOI : 10.14710/transmisi.21.4.116-127 | Hal. 123 


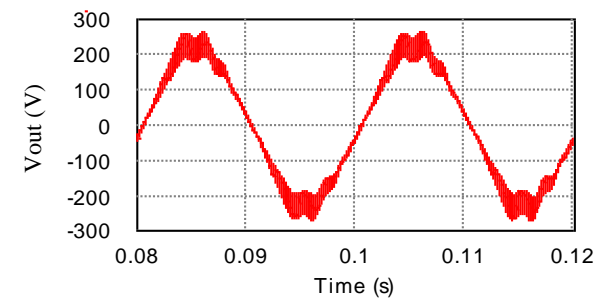

Gambar 25. Grafik $V_{\text {out }}$ boost inverter SPWM bipolar dengan pengendali PID $V_{\text {in }} 48$ volt menjadi 47,4 volt

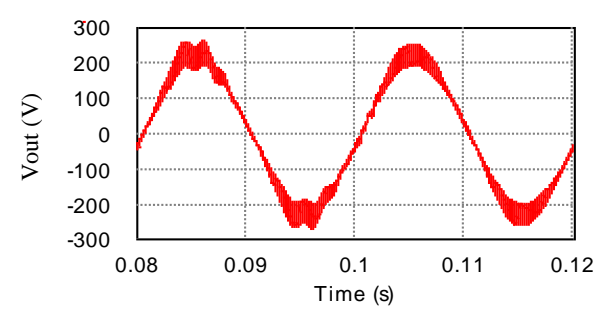

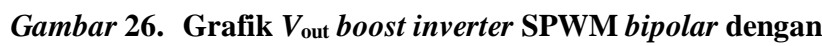
pengendali PID $V_{\text {in }} 48$ volt menjadi 60 volt

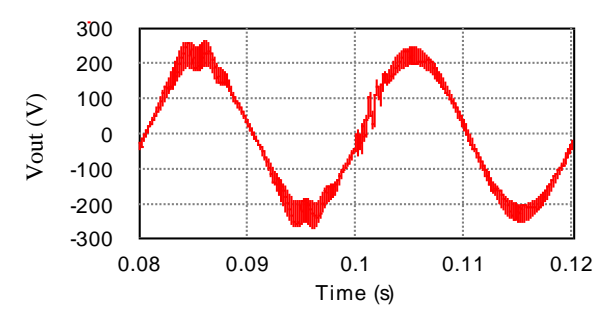

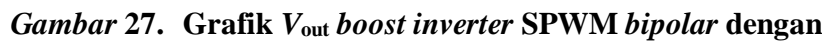
pengendali PID $V_{\text {in }} 48$ volt menjadi 96 volt

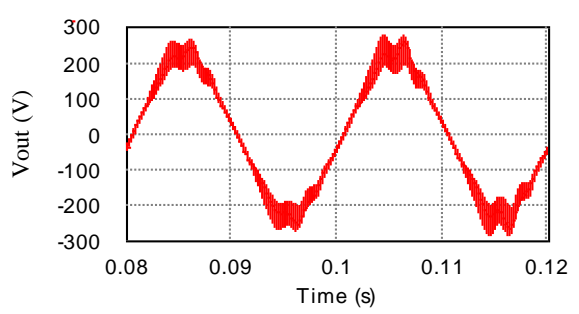

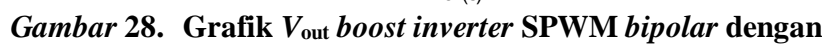

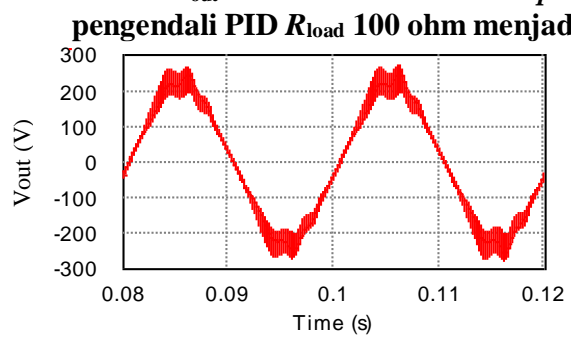

Gambar 29. Grafik $V_{\text {out }}$ boost inverter SPWM bipolar dengan pengendali PID $R_{\text {load }} 100 \mathrm{ohm}$ menjadi $95 \mathrm{ohm}$

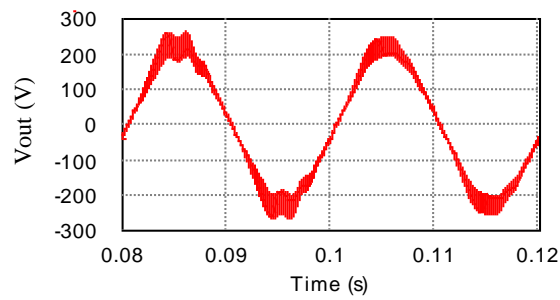

Gambar 30. Grafik $V_{\text {out }}$ boost inverter SPWM bipolar dengan pengendali PID $R_{\text {load }} 100 \mathrm{ohm}$ menjadi $125 \mathrm{ohm}$

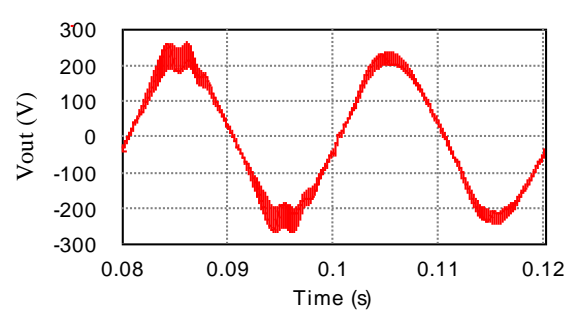

Gambar 31. Grafik $V_{\text {out }}$ boost inverter SPWM bipolar dengan pengendali PID $R_{\text {load }} 100 \mathrm{ohm}$ menjadi $200 \mathrm{ohm}$

Boost inverter SPWM unipolar dengan pengendali PID diberi gangguan berupa perubahan nilai $V_{\text {ref, }} V_{\text {in }}$, dan $R_{\text {load }}$ pada waktu ke-0,1 detik. Gangguan diberikan dengan tujunan untuk mengetahui kinerja pengendali PID pada boost inverter pensakelaran SPWM unipolar. Hasil simulasi pemberian gangguan tersebut ditunjukkan pada Gambar 32-40.

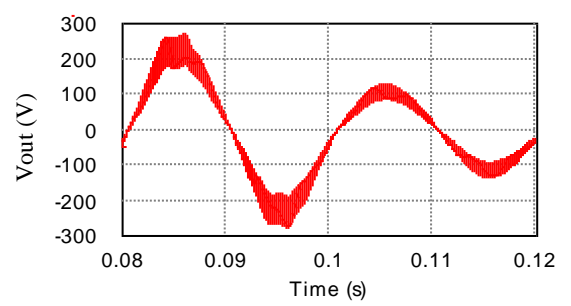

Gambar 32. Grafik $V_{\text {out }}$ boost inverter SPWM unipolar pengendali PID $V_{\text {ref }} 220$ volt menjadi 110 volt

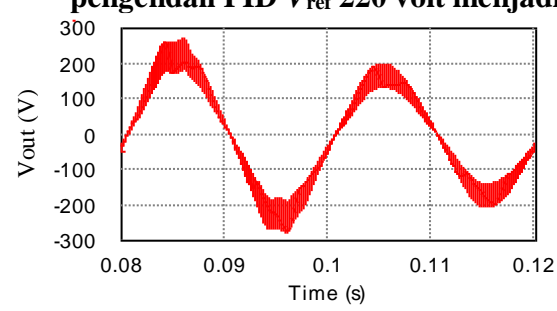

Gambar 33. Grafik $V_{\text {out }}$ boost inverter SPWM unipolar pengendali PID $V_{\text {ref }} 220$ volt menjadi 165 volt 


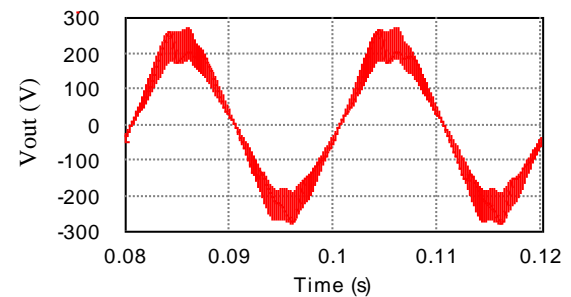

Gambar 34. Grafik $V_{\text {out }}$ boost inverter SPWM unipolar pengendali PID $V_{\text {ref }} 220$ volt menjadi 222 volt

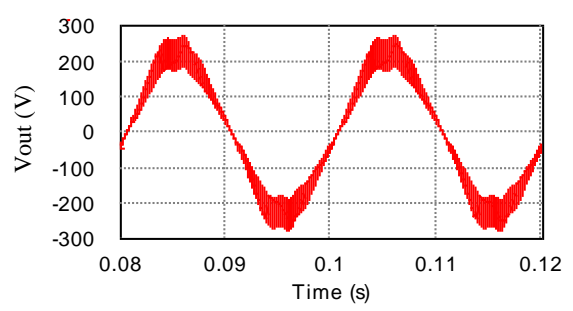

Gambar 35. Grafik $V_{\text {out }}$ boost inverter SPWM unipolar pengendali PID $V_{\text {in }} 48$ volt menjadi 47,4 volt

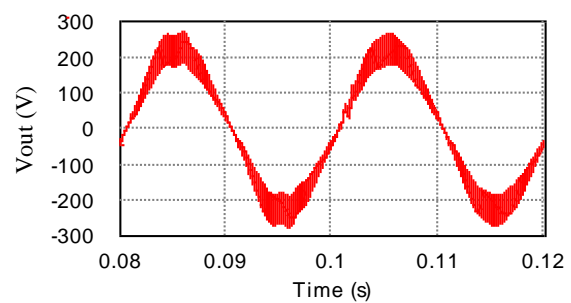

Gambar 36. Grafik $V_{\text {out }}$ boost inverter SPWM unipolar pengendali PID $V_{\text {in }} 48$ volt menjadi 60 volt

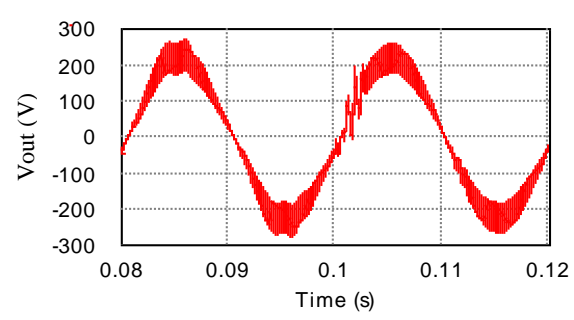

Gambar 37. Grafik $V_{\text {out }}$ boost inverter SPWM unipolar

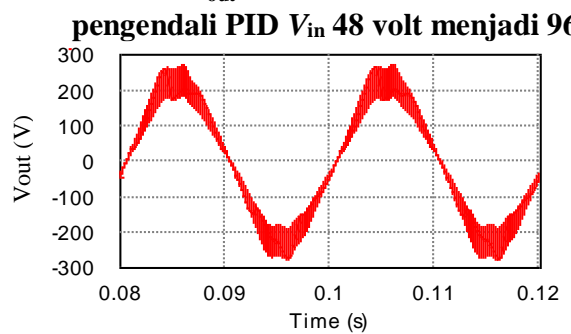

Gambar 38. Grafik $V_{\text {out }}$ boost inverter SPWM unipolar pengendali PID $R_{\text {load }} 100 \mathrm{ohm}$ menjadi $95 \mathrm{ohm}$

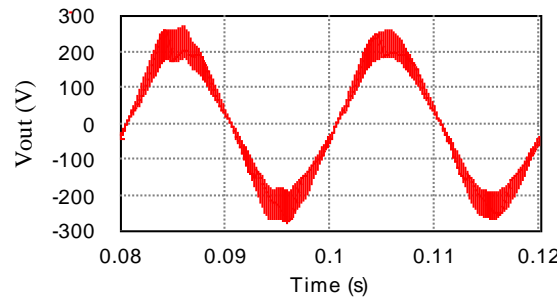

Gambar 39. Grafik $V_{\text {out }}$ boost inverter SPWM unipolar pengendali PID $R_{\text {load }} 100 \mathrm{ohm}$ menjadi $125 \mathrm{ohm}$

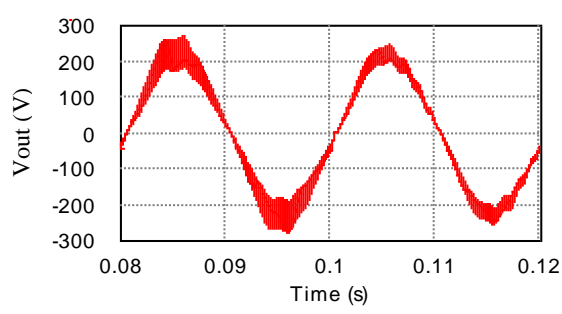

Gambar 40. Grafik $V_{\text {out }}$ boost inverter SPWM unipolar pengendali PID $R_{\text {load }} 100 \mathrm{ohm}$ menjadi $200 \mathrm{ohm}$

\subsection{Perbandingan Kinerja Boost Inverter dengan Pengendali PID SPWM Bipolar dan Unipolar}

Berdasarkan Gambar 16-19 maka diperoleh perbandingan hasil simulasi boost inverter dengan pengendali PID SPWM bipolar dan unipolar, yang ditunjukkan pada Tabel 9, Gambar 41 dan 42.

Tabel 9. Perbandingan Boost Inverter dengan Pengendali PID Antara SPWM Bipolar dengan Unipolar

\begin{tabular}{lllll}
\hline \multirow{2}{*}{ No. } & \multirow{2}{*}{ Parameter } & \multicolumn{2}{c}{ Nilai SPWM } & \multirow{2}{*}{ Satuan } \\
\cline { 3 - 4 } & & Bipolar & Unipolar & \\
\hline 1. & $V_{\text {out }}$ & 220,11 & 220,39 & V \\
2. & lout $_{3 .}$ & 2,2 & 2,2 & $\mathrm{~A}$ \\
3. & $T H D_{\text {Vout }}$ & 5,36 & 4,6 & $\%$ \\
4. & $T H D_{\text {lout }}$ & 5,36 & 4,6 & $\%$ \\
\hline
\end{tabular}

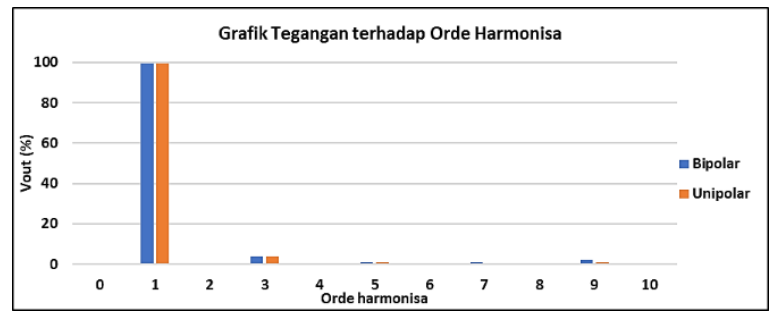

Gambar 41. Grafik perbandingan $V_{\text {out }}$ terhadap orde harmonisa boost inverter pengendali PID SPWM bipolar dan unipolar 


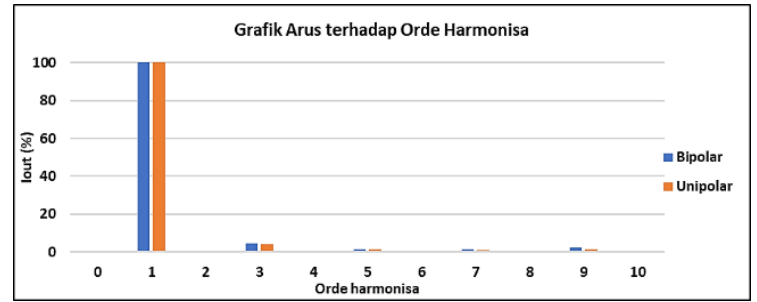

Gambar 42. Grafik perbandingan $I_{\text {out }}$ terhadap orde harmonisa boost inverter pengendali PID SPWM bipolar dan unipolar

Berdasarkan Gambar 20-23 untuk SPWM bipolar dan Gambar 32-34 untuk SPWM unipolar diperoleh perbandingan kinerja boost inverter dengan pengendali PID seperti yang ditunjukkan pada Tabel 10.

Tabel 10.Perbandingan Boost Inverter Pengendali PID SPWM Bipolar dan Unipolar Vref Berubah

\begin{tabular}{|c|c|c|c|c|c|c|c|}
\hline \multirow{2}{*}{ No } & \multirow{2}{*}{$\begin{array}{l}V_{\text {ref }} \\
\text { (V) }\end{array}$} & \multirow{2}{*}{$\begin{array}{l}V_{\text {in }} \\
\text { (V) }\end{array}$} & \multirow{2}{*}{$\begin{array}{l}R_{\text {load }} \\
\text { (ohm) }\end{array}$} & \multicolumn{2}{|c|}{$V_{\text {out }}$ (volt) } & \multicolumn{2}{|c|}{ Error (\%) } \\
\hline & & & & Bipolar & Unipolar & Bipolar & Unipolar \\
\hline 1. & 110 & 48 & 100 & 108,50 & 109,14 & 1,36 & 0,78 \\
\hline 2. & 165 & & & 163,88 & 164,44 & 0,68 & 0,34 \\
\hline 3. & 220 & & & 220,11 & 220,39 & 0,05 & 0,18 \\
\hline 4. & 222 & & & 222,16 & 222,38 & 0,07 & 0,17 \\
\hline 5. & 228 & & & 228,53 & - & 0,23 & - \\
\hline
\end{tabular}

Berdasarkan Gambar 24-27 untuk SPWM bipolar dan Gambar 35-37 untuk SPWM unipolar diperoleh perbandingan kinerja boost inverter dengan pengendali PID seperti yang ditunjukkan pada Tabel 11.

Tabel 11.Perbandingan Boost Inverter Pengendali PID SPWM Bipolar dan Unipolar $V_{\text {in }}$ Berubah

\begin{tabular}{llllllll}
\hline \multirow{2}{*}{ No } & $\boldsymbol{V}_{\text {ref }}$ & $\boldsymbol{V}_{\text {in }}$ & $\boldsymbol{R}_{\text {load }}$ & \multicolumn{2}{l}{$\boldsymbol{V}_{\text {out }}($ volt) } & \multicolumn{3}{c}{ Error (\%) } \\
\cline { 5 - 8 } & $(\mathbf{V})$ & $(\mathbf{V})$ & $($ Ohm $)$ & bipolar & unipolar & bipolar & unipolar \\
\hline $\mathbf{1 .}$ & 220 & 46 & 100 & 220,52 & - & 0,24 & - \\
$\mathbf{2 .}$ & & 47,4 & & 220,15 & 220,36 & 0,07 & 0,17 \\
$\mathbf{3}$ & & 48 & & 220,11 & 220,39 & 0,05 & 0,18 \\
$\mathbf{4 .}$ & & 60 & & 219,67 & 220,33 & 0,15 & 0,15 \\
$\mathbf{5 .}$ & & 96 & & 219,82 & 221,09 & 0,08 & 0,49 \\
\hline
\end{tabular}

Berdasarkan Gambar 28-31 untuk SPWM bipolar dan Gambar 38-40 untuk SPWM unipolar diperoleh perbandingan kinerja boost inverter dengan pengendali PID seperti yang ditunjukkan pada Tabel 12 .

Tabel 12. Perbandingan Boost Inverter Pengendali PID SPWM Bipolar dan Unipolar $\mathbf{R}_{\text {load }}$ Berubah

\begin{tabular}{|c|c|c|c|c|c|c|c|}
\hline \multirow{2}{*}{ No } & \multirow{2}{*}{$\begin{array}{l}V_{\text {ref }} \\
\text { (V) }\end{array}$} & \multirow{2}{*}{$\begin{array}{l}\text { Vin } \\
\text { (V) }\end{array}$} & \multirow{2}{*}{$\begin{array}{l}R_{\text {load }} \\
(\text { Ohm) }\end{array}$} & \multicolumn{2}{|c|}{$V_{\text {out }}($ Volt $)$} & \multicolumn{2}{|c|}{ Error (\%) } \\
\hline & & & & bipolar & unipolar & bipolar & unipolar \\
\hline 1. & 220 & 48 & 87,4 & 221,06 & - & 0,48 & - \\
\hline 2. & & & 95 & 220,41 & 220,69 & 0,19 & 0,32 \\
\hline 3. & & & 100 & 220,11 & 220,39 & 0,05 & 0,18 \\
\hline 4. & & & 125 & 219,04 & 219,31 & 0,44 & 0,31 \\
\hline 5. & & & 200 & 217,79 & 217,97 & 1 & 0,92 \\
\hline
\end{tabular}

Berdasarkan Tabel 10, 11 dan 12 dapat dikatakan bahwa boost inverter dengan pengendali PID pada SPWM bipolar dapat bekerja dengan rentang nilai $V_{\text {ref }}, V_{\text {in }}$ dan $R_{\text {load }}$ yang lebih banyak dibandingkan dengan SPWM unipolar. Dapat diamati bahwa nilai THD tegangan dan arus keluaran pada boost inverter satu fasa pengendali PID lebih baik, yaitu sebesar 5,36\% untuk SPWM bipolar dan 4,6\% untuk SPWM unipolar, dibandingkan dengan tanpa pengendali PID yaitu sebesar 19,69\% untuk SPWM bipolar dan 19,78\% untuk SPWM unipolar. Hasil perolehan THD dengan pengendali PID pada penelitian lebih baik dibandingkan dengan hasil yang diperoleh menggunakan metode pada penelitian sebelumnya [5].

Tegangan keluaran pada boost inverter satu fasa tanpa pengendali PID sebesar 221,88 volt untuk SPWM bipolar dan 220,73 volt untuk SPWM unipolar, sedangkan tegangan keluaran pada boost inverter satu fasa dengan pengendali PID sebesar 220,11 volt untuk SPWM bipolar dan 220,39 volt untuk SPWM unipolar. Kinerja pengendali PID pada boost inverter untuk SPWM bipolar dan unipolar ketika diberikan gangguan berupa perubahan nilai $\mathrm{V}_{\text {ref }}, \mathrm{V}_{\text {in }}$ dan $\mathrm{R}_{\text {load }}$ cukup baik, yang ditunjukkan dengan nilai $V_{\text {out }}$ yang cenderung stabil pada 220 volt.

\section{Kesimpulan}

Berdasarkan pembahasan hasil simulasi yang sudah dilakukan, dapat diambil kesimpulan bahwa Hasil penelitian menunjukkan bahwa penggunaan pengendali PID dapat mengurangi nilai total distorsi harmonisa pada boost inverter satu fasa. Penggunaan pengendali PID pada teknik penyakelaran SPWM bipolar menghasilkan pengurangan nilai total distorsi harmonisa hingga sebesar $72,8 \%$, sedangkan pada teknik penyakelaran SPWM unipolar diperoleh pengurangan sebesar hingga 76,7\%. Hasil simulasi juga menunjukkan bahwa besar tegangan dan arus keluaran tetap dapat dipertahankan pada nilai yang diinginkan ketika terjadi gangguan.

\section{Referensi}

[1]. Subroto RK, Ardhenta L, Maulana E. A Novel of Adaptive Sliding Mode Controller with Observer for DC/DC Boost Converters in Photovoltaic System. 5th International Conf on Electrical, Electronics and Information Engineering (ICEEIE). Malang. 2017: 9-14.

[2]. Das HS, Tan CW, Yatim AHM, Muhammad NDB. Analysis and Control of Boost Inverter for Fuel Cell Applications. IEEE International Conference on Power and Energy (PECon). Melaka. 2016: 455-460.

[3]. Xiong Y, Qian S, Xu J. Single-Phase Grid-Connected Photovoltaic System Based on Boost Inverter. AsiaPacific Power and Energy Engineering Conference (APPEEC). Shanghai. 2012: 1-3.

[4]. Caceres R, Barbi I. A boost DC-AC converter: analysis design and experimentation. IEEE Transactions on Power Electronics. 1999, 14(1): 134-141.

[5]. Menaka S, Muralidharan S. Design and Performance Analysis of Novel Boost DC-AC Converter. 3rd International Conference on Electronics Computer Technology (ICECT). Kanyakumari. 2011, 2: 168-172. 
[6]. Rachmildha TD, Haroen Y, Muqorobin A, Rijanto E. Single Phase Boost Inverter Using Hybrid Modelling Approach. IEEE Conf on Power Engineering and Renewable Energy. Bali. 2012: 1-6.

[7]. Haroen Y. Elektronika Daya. Bandung: ITB Press. 2018: 197-199.

[8]. Namboodiri A, Wani HS. Unipolar dan Bipolar PWM Inverter. International Journal for Innovative Research in Science \& Technology (IJIRST). 2014, 1(7): 237-243.

[9]. Caceres R, Rojas R, Camacho O. Robust PID Control of A Buck-Boost DC-AC Converter. Proc. IEEE Int. Conf. Telecommunications Energy. Phoenix. 2000: 180-185.

[10]. Martins FG. Tuning PID Controllers using the ITAE Criterion*. International Journal of Engineering Education. 2005, 21(5): 867-873.

[11]. Awouda AEA, Mamat RB. Refine PID tuning rule using ITAE criteria. 2010 The 2nd International Conference on Computer and Automation Engineering (ICCAE). Singapore, Singapore. 2010, 5: 171-176.
[12]. Cherati SM, Azli NA, Ayob SM, Mortezaei A. Design of A Current Mode PI Controller for A Single-Phase PWM Inverter. IEEE Applied Power Electronics Colloquium (IAPEC). Johor Bahru. 2011: 180-184.

[13]. Caceres R, Barbi I. A boost dc-ac converter: Operation analysis control and experimentation. Proc of IECON '95 - 21st Annual Conference on IEEE Industrial Electronics. Orlando. 1995: 546-551.

[14]. Wahyunggoro O, Wibawa H, Cahyadi AI. Speed control simulation of DC servomotor using hybrid PID-fuzzy with ITAE polynomials initialization. 2017 International Conference on Computer, Control, Informatics and its Applications (IC3INA). Jakarta, Indonesia. 2017: 95-99.

[15]. Xing N, Lin Y, Zhang J. Some improvements on eventbased PID controllers. Proceedings of the 32nd Chinese Control Conference. Xi' an, China. 2013: 6622-6627.

[16]. Maurya AK, Bongulwar MR, Patre BM. Tuning of fractional order PID controller for higher order process based on ITAE minimization. 2015 Annual IEEE India Conference (INDICON). New Delhi, India. 2015: 1-5. 